\title{
Ireland
}

\section{New Merger Control Reporting Thresholds}

\author{
Ronan Dunne*
}

\section{Introduction}

The Irish Minister for Business, Enterprise and Innovation signed the Competition Act 2002 (Section 27) Order 2018 (the Order) on 2 October. ${ }^{1}$ The Order was subsequently confirmed by the houses of the Irish parliament (ie, the Dáil and the Seanad) on 16 October 2018. The Order has the effect of increasing the financial thresholds for mandatory notification of a merger or acquisition to the Competition and Consumer Protection Commission (CCPC) in Ireland and will come into effect as and from 1 January 2019.

This is the first time that a Minister has used his or her powers under section 27 of the Competition Acts 2002 to 2017 (the Competition Act) to increase the financial thresholds for deal reporting since the introduction of the current thresholds on 31 October 2014.

\section{Current Regime}

Under current rules, it is mandatory for a 'merger or acquisition' (as that term is defined by reference to section 16(1) of the Competition Act) to be notified to the CCPC where it meets the following cumulative financial thresholds, by reference to the most recent financial year:

1. the aggregate turnover in the Republic of Ireland (the State) of the undertakings involved in a

DOI: $10.21552 /$ core/2018/4/9

* Ronan Dunne is a partner at Philip Lee in Dublin, Ireland, where he leads the EU, Competition and State Aid practice group. For correspondence: <rdunne@philiplee.ie>.

1 Competition Act 2002 (Section 27) Order 2018, SI No 388 of $2018<$ https://dbei.gov.ie/en/Legislation/Legislation-Files/SI-No -388-of-2018.pdf> accessed 26 November 2018.

2 Department of Business, Enterprise and Innovation, 'Consultation on a review of certain provisions under the Competition Act 2002, as amended, relating to merger and acquisitions' (September 2017) <https://dbei.gov.ie/en/Consultations/Consultations-files/Consultation -review-certain-provisions-Competition-Act-2002-as-amended -merger-and-acquisitions.pdf> accessed 26 November 2018. proposed merger or acquisition was not less than $€_{50}$ million, and

2. the turnover in the State of each of two or more undertakings involved in the proposed merger or acquisition was not less than $€_{3}$ million.

These thresholds are set out in section 18(1)(a) of the Competition Act.

\section{New Regime}

As and from 1 January 2019, mergers and acquisitions must be notified to the CCPC where, in the most recent financial year:

1. the aggregate turnover in the State of the undertakings involved in a proposed merger or acquisition was not less than $€ 60$ million, and

2. the turnover in the State of each of two or more undertakings involved in the proposed merger or acquisition was not less than $€ 10$ million.

In effect, the changes being introduced will increase the current $€_{50}$ million aggregate turnover threshold to $€ 6 \circ$ million and the $€_{3}$ million individual turnover threshold to $€ 10$ million.

\section{Factors Giving Rise to the New Regime}

A public consultation on the merger control provisions of the Competition Act was initiated by the Irish Department of Business, Enterprise and Innovation (DBEI) in September 2017 (appropriately named the 'Consultation on a review of certain provisions under the Competition Act 2002, as amended, relating to merger and acquisitions ${ }^{\prime 2}$ ). The new financial thresholds for deal reporting, as set out in the Order, amount to a culmination of this process. 
The existing financial thresholds were introduced on 31 October 2014. They significantly amended the previous reporting thresholds (including by removing a reference to a business's worldwide turnover), with the express intention of focussing on transactions with a nexus to the State. However, those thresholds were set at a level which had the result of significantly increasing the number of mergers and acquisitions notified to the CСPC in the following years. Thus, for example, there was a clear contrast with the number of deals notified to the CCPC in the calendar year 2013 of 37, and those in the following years as the number of notifications per annum significantly increased to 78 in 2015, 67 in 2016, 72 in 2017 and, as of 21 November 2018, 89 for the year to date for 2018 .

Many of the notified transactions in recent years did not, on their face, give rise to any competition concerns whatsoever. Indeed, a significant number concerned acquisitions of individual retail units (including, in particular, motor fuel stations) and commercial property assets (such as office blocks, hotels and shopping centres). The DBEI consultation process was designed to review the financial reporting thresholds in this light. The process highlighted how increasing the individual turnover in the State threshold, for two or more undertakings in a transaction, from $€_{3}$ million to $€ 10$ million could - in and of itself - reduce the number of notified transactions by up to $40 \%$ on a per annum basis (by reference to those deals notified to the CCPC in 2015 and 2016). By contrast, the proposed higher financial threshold for the aggregate turnover of the undertakings involved, ie, the increase from $€_{50}$ million to $€ 60$ million from 1 January 2019, would have only resulted in 4 fewer notified transactions in 2015 and 2 fewer notified transactions in 2016.

In addition, the DBEI consultation involved review of the merger control regimes applicable in a number of other European countries, namely Austria, Belgium, Bulgaria, Croatia, Cyprus, Czech Republic, Denmark, Finland, France, Germany, Greece, Hungary, Italy, Norway, Portugal, Sweden and Switzerland. The revised regime for Ireland is intended to align this jurisdiction with many similarly sized European jurisdictions.

\section{Other Changes}

No other changes will be introduced by way of the Order, which was solely focussed on increasing the relevant financial thresholds for the reporting of mergers and acquisitions to the CCPC under the current Irish regime.

The DBEI consultation also considered whether amendment was required to the timeframes for deal review by the CCPC (either to increase or decrease same, as appropriate). Ultimately, however, no changes were proposed in this regard at the end of the consultation process.

Further, and unlike recent moves in other European countries such as Germany and Austria, it is worth highlighting that there is no Irish 'transaction value' threshold to capture mandatory notification of deals involving high consideration but businesses with low turnover (potentially such as digital businesses or high value start-ups). This issue was not considered in the context of the DBEI consultation, presumably on the basis that any amendment to the Competition Act to include a transaction value threshold would need to be made by way of primary legislation. By contrast, the Competition Act expressly permits the Minister to increase the financial thresholds for mandatory deal reporting by way of secondary legislation (ie, through a statutory instrument, effectively a Ministerial order in this instance). As such, the changes in the Order were significantly easier to introduce from a legislative perspective than would have been the case were an amending act required. As a general rule, it can take a significant amount of time for primary legislation to be approved and enacted through the Irish parliamentary process.

\section{Comment}

The revised financial thresholds have been broadly welcomed by business leaders on the expectation that they will result in a sharp decrease in the level of mandatory notifications arising in the context of Irish related mergers and acquisitions. Indeed, the revised regime will likely facilitate both national and international businesses who may be seeking to either consolidate their Irish business interests or expand into the Irish market by way of acquisition.

In addition, the DBEI consultation suggests that the vast majority of the deals which will now be excluded from mandatory notification as a result of these changes would not give rise to any adverse competition effects by reference to its study of notifica- 
tions made in 2015 and 2016. Indeed, any decrease in the number of annual notifications may allow the CCPC to better allocate its resources and focus on those transactions which may potentially give rise to competition law concerns.

The costs of making a notification to the CCPC were highlighted in parliamentary discussions regarding amendment of the financial thresholds (both in terms of the obligatory filing fee payable to the CCPC and associated legal costs relating to the drafting of the merger notification form and liaising with the relevant authorities). These were effectively perceived as an additional form of business cost, the burden of which will now be removed under the new regime for those transactions which will no longer require notification.

To be clear, the CCPC has powers to investigate mergers and acquisitions that fall below the revised thresholds in all events, where any merger or acquisition is perceived to raise potential competition law concerns. On that basis it remains advisable for clients to ensure their deals do not give rise to adverse competition effects even where mandatory notification is not required pursuant to the revised Irish merger control reporting regime. The effects-based test for any merger or acquisition remains whether a proposed transaction could substantially lessen competition in a market in Ireland, and this remains unchanged. 